\title{
Low Number of Neuroinfections in Migrants to Greece from Syria and Iraq Comparison to Migrants from Burundi and Congo to Rwanda
}

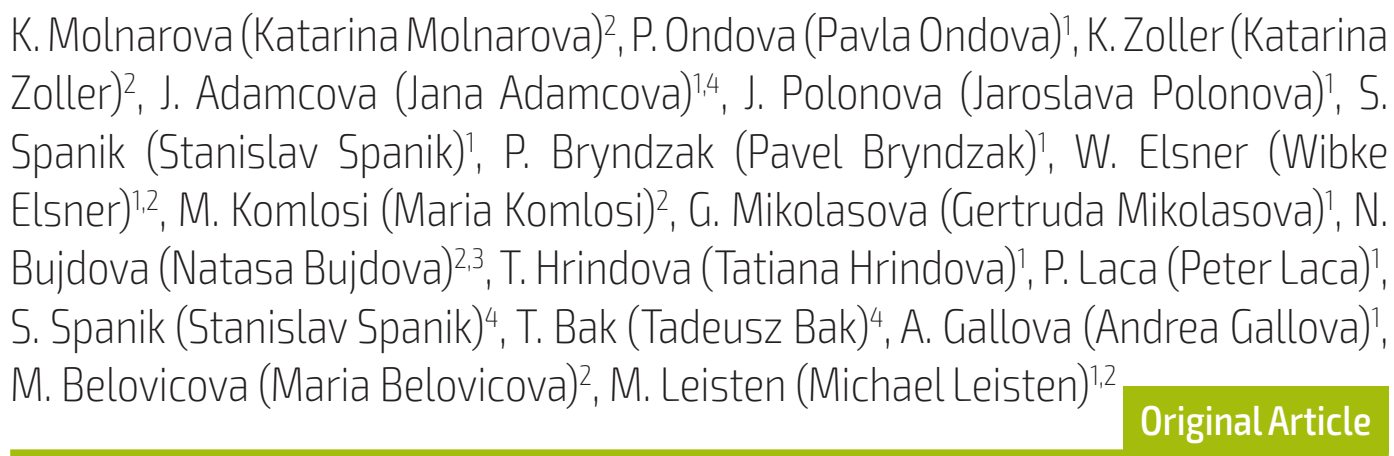

1 Tropical Institute of St. Elisabeth University, PhD, MPH Programe, Slovakia

2 Tropical MPH and MSc Programe SEU, Slovakia

3 Tropical and refugee program of St. Elisabeth University, SW Post, OSE Observers, Mariupol, Ukraine

${ }^{4}$ St. Elisabeth University of Health and Social Sciences, PhD programe Bratislava, Slovakia

\section{E-mail address:}

natasabujdova@gmail.com

\section{Reprint address:}

Natasa Bujdova, M.D.

DSW Mariupol

Health post Ukraine

Suource: Clinical Social Work and Health Intervention Pages: $16-18$

\section{Reviewers:}

Jirina Kafkova, Ph.D.

Nairobi, St. Bakitha Clinic, Kenya

Victor Namulanda Wanjala

Catholic university of Eastern Africa, Nairobi, Kenya

\section{Key words:}

Migrants, Neuroinfections.

\section{Publisher:}

International Society of Applied Preventive Medicine i-gap 
CSWHI 2017; 8(2): 16 - 18; DOI 10.22359/cswhi_8_2_03 @ 2017 Clinical Social Work and Health Intervention

\section{Abstract:}

The aim of this short paper was to assess proportion of neuroinfections in refugees from Syria and Iraq in comparison to those fleeing from Congo and Burundi to Rwanda. Screening on neuroinfections was performed in both populations and compared in univariate analysis.

\section{Conflict of interest:}

The authors whose names are listed in the title of the article certify that they have NO affiliations with or involvement in any organization or entity with any financial interest (such as honoraria; educational grants; participation in speakers' bureaus; membership, employment, consultancies, or other equity interest), or non-financial interest (such as personal or professional relationships, affiliations, knowledge or beliefs) in the subject matter or materials discussed in this manuscript.

\section{Introduction}

Little has been published on neuroinfections and mainly on poliomyelitis and their long-term neurological complications and consequences related to migrant populations. Two groups of refugees from populations where poliomyelitis was not yet eradicated are entering EU either African migrants from Nigeria, Somalia, Sudan via Sicily and Malta, or migrants from Iraq, Iran, Pakistan via Balkan route. Despite of significant numbers of migrants, no poliomyelitis case was observed or described. Vaccination status of migrating populations remain mostly unknown, but we can suppose lack of vaccines in conflict zones. There is a need for screening of neurological symptoms in migrant populations and their vaccination status.

\section{Patients and methods}

All arriving migrants/refugees to Alexandropolis UNHCR camp Health Clinic of St. Elisabeth University are standardly screened for TB, STD including HIV and hepatis B and C. Except these standard screenings, also screening for neurological symptoms which could show latent neuroinfections was added. In two weeks, in total of 632 migrants was screened for neurological symptoms. Same screening was done on group of 91 newly arrived migrants in UNHCR camp in Rwanda. Both groups were assessed and compared by univariate analysis.

\section{Results}

For both groups, no neuroinfection or neurological symptoms were found. However, in group of migrants from Alexandropolis, in 10 cases, symptoms of posttraumatic stress disorder (PTSD) were found and patients were referred to adequate specialists. 1 case of epilepsy was noted during routine screening.

\section{Conclusions}

Neurological symptomatology in both groups of migrants either African or from Middle East is rare. 


\section{References}

1. MANZARDO C, TREVIGNO B, GOMEZ I PRAT J, CABEZOS J ET AL (2008). Communicable diseases in the immigrant population attended to in a tropical medicine unit: Epidemiological aspects and public health issue. Travel Medicine and Infectious Disease, 2008 Vol. 6, Issue 1, Pages 4-11.

2. PRESTILEO T, CASSARA G, DI LORENZO F, SANFILIPPO A, DALLE NOGARE E R, ORLANDO G (2011). Infectious diseases and health in the migrant people: experience from Lampedusa 2011. Infezioni in Medicina: 2013. 17-24 - Vol. 21.

3. KAFKOVA J, SILHAROVA B, KRCMERY V, ABDO HASAN A (2017). Late presenters among HIV-positive patients, attending a rural comprehensive care clinic in Southern Uganda. ECCMID 2017.

4. SZABO I, KULKOVA N, SOKOLOVA J, MIKOLASOVA G, SUVADA J, KALAVSKA A, DOBRODENKOVA S, MATEICKA F, KAFKOVA J, NKONWA I (2013).
Neurologic complications and sequellae of infectious diseases in Uganda and Kenya: Analysis of 288 cases from two rural hospitals. In Neuroendocrinology Letters Vol. 34, Suppl 1, 2013, Pages 28-31.

5. STAWECKA A (2015). A teacher in relation to early school age "Euro-orphans" mental health. In Health and Social Work. ISSN 13336-9326. Vol. 10, Suppl. p. 210212.

6. E. MUSILOVA (2016). Rehabilitation treatment of pain at upper cross-syndrome, REHABILITATION 3, XLIII(53), ISSN 0375-0922, s. $174-185$.

7. MOLNAROVA K, HES D, KRCMERY V, MIKOLASOVA G, MICHALIKOVA L, JACKO L, JANKECHOVA M, KURNAT A (2015). Infectious diseases on Rwanda DR Congo border UNHCR camp. In Clinical Social Work and Health intervention. DOI: $10.5604 / 2222386 X$. 